"The impact of credit risk and macroeconomic factors on profitability: the case of the ASEAN banks"

\begin{tabular}{|c|c|}
\hline AUTHORS & Myra V. De Leon ED http://orcid.org/0000-0001-7270-0151 \\
\hline ARTICLE INFO & $\begin{array}{l}\text { Myra V. De Leon (2020). The impact of credit risk and macroeconomic factors on } \\
\text { profitability: the case of the ASEAN banks. Banks and Bank Systems, 15(1), } 21 \text { - } \\
\text { 29. doi:10.21511/bbs.15(1).2020.03 }\end{array}$ \\
\hline DOI & http://dx.doi.org/10.21511/bbs.15(1).2020.03 \\
\hline RELEASED ON & Friday, 21 February 2020 \\
\hline RECEIVED ON & Saturday, 02 November 2019 \\
\hline \multirow[t]{2}{*}{ ACCEPTED ON } & Tuesday, 28 January 2020 \\
\hline & $(c))_{E Y}$ \\
\hline LICENSE & $\begin{array}{l}\text { This work is licensed under a Creative Commons Attribution } 4.0 \text { International } \\
\text { License }\end{array}$ \\
\hline JOURNAL & "Banks and Bank Systems" \\
\hline ISSN PRINT & $1816-7403$ \\
\hline ISSN ONLINE & $1991-7074$ \\
\hline PUBLISHER & LLC "Consulting Publishing Company "Business Perspectives" \\
\hline FOUNDER & LLC "Consulting Publishing Company "Business Perspectives" \\
\hline & 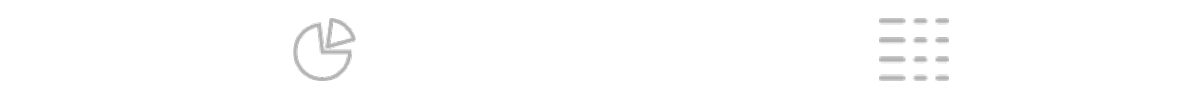 \\
\hline NUMBER OF REFERENCES & NUMBER OF FIGURES \\
\hline 36 & 0 \\
\hline
\end{tabular}

(C) The author(s) 2021. This publication is an open access article. 


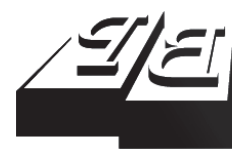

\section{BUSINESS PERSPECTIVES}

9

LLC "CPC "Business Perspectives"

Hryhorii Skovoroda lane, 10,

Sumy, 40022, Ukraine

www.businessperspectives.org
Received on: $2^{\text {nd }}$ of November, 2019 Accepted on: $28^{\text {th }}$ of January, 2020 Published on: $21^{\text {th }}$ of February, 2020

(c) Myra V. De Leon, 2020

Myra V. De Leon, Ph.D. Student, RVR College of Business, De La Salle University, Philippines.
This is an Open Access article, distributed under the terms of the Creative Commons Attribution 4.0 International license, which permits unrestricted re-use, distribution, and reproduction in any medium, provided the original work is properly cited.

Conflict of interest statement: Author(s) reported no conflict of interest

Myra V. De Leon (Philippines)

\title{
THE IMPACT OF CREDIT RISK AND MACROECONOMIC FACTORS ON PROFITABILITY: THE CASE OF THE ASEAN BANKS
}

\begin{abstract}
This study investigates the effect of credit risk and macroeconomic factors on profitability of 20 ASEAN banks, particularly from Indonesia, Malaysia, Thailand and Philippines, covering the period of 2012 to 2017. The unbalanced panel data were tested for heteroscedasticity and normality. A fixed effects model and a random effects model were utilized followed by simple ordinary least squares (OLS) regression. The obtained results show that credit risk and GDP growth negatively affect Return on Equity (ROE) at $5 \%$ level of significance. The inflation rate increases ROE by $0.323 \%$. In terms of influence, inflation has the highest impact on ROE followed by GDP growth and credit risk. Credit risk and GDP growth negatively affect Return on Assets (ROA) at 5\% level of significance. ROA was also influenced by an increase in inflation rate. Therefore, this study will help banks and bank managers, depositors, investors, policy makers and governments to identify factors affecting bank profitability.
\end{abstract}

\section{Keywords}

JEL Classification

\section{INTRODUCTION}

The banks' financial intermediation functions are one of the most significant factors for the development of the economy (Elsas, Hackethal, \& Holzhäuser, 2010). More profitable financial institutions, like banks, entail more transfer of wealth to the economy (Hirose, Murakami, \& Oku, 2004; Kohler, 2013; Maudos \& Guevara, 2004; Saunders \& Schumacher, 2000). The profitable banking sector is better able to withstand adverse shocks and contribute to financial system stability (Ani, Ugwunta, Ezeudu, \& Ugwuanyi, 2012).

Based on the 2015 BBVA survey, profitability of ASEAN banks is decreasing but still high (Deorukhkar \& Xia, 2015). Average ROE of ASEAN banks is $12.6 \%$ compared to the world average of $12 \%$, considering the ROE of Indonesian banks at $21.5 \%$. ROA declined for Indonesia, Philippines, Malaysia and Thailand, with significant changes for Indonesian banks from 3.1\% in 2013 to $2.3 \%$ in the third quarter of 2015. As of 2017, the profitability of ASEAN banks has been stable as compared to the past three years with the economic slowdown (Vidal-Abarca, Xia, Deorukhkar, Rodrgo, \& Ugarte, 2017).

Existing studies have shown that determinants of profitability are internal or external factors (Wasiuzzaman \& Tarmizi, 2010; Masood, Ashraf, \& Turen, 2015). Unlike some previous studies that were country-specific (Ani et al., 2012), the aim of this study is to examine whether credit risk, GDP growth rate and inflation rate affect the 
profitability of the top five ASEAN-4 banks for the years 2012-2017. Profitability was measured by ROE and ROA. As there are similarities in economies and other banking policies, ASEAN-4 banks from Indonesia, Malaysia, Thailand and Philippines were chosen for this study.

\section{LITERATURE REVIEW}

ASEAN integration intends to establish a sole Southeast Asian market with free flow of goods, services, investments, capital and labor (ASEAN Secretariat, 2008). According to Asian Development Bank (2013), 82\% of the total 2009 financial assets belong to commercial banks. Therefore, commercial banks are the dominant financial institutions in the ASEAN region.

Profitability is a substantial indicator of financial performance of banks (Zarrouk, 2012). ROE is mostly used as a profitability measure, as it reflects the financial leverage, profitability, and efficiency (Muhamet \& Arbana, 2016). Other studies utilize ROA as a profitability ratio because it reflects the bank's efficiency in accumulating profits from its assets (Gizaw, Kedebe, \& Selvaraj, 2015).

Internal factors, including credit risk, affected the profitability of commercial banks in Kenya based on Ongore and Kusa (2013). Studies of Ahmad, Nafees, and Khan (2012), Ahmad, Tahir, and Aziz (2014) and Mustafa, Ansari, and Younis (2011) on banks of Pakistan have shown that credit risk has a negative and significant impact on profitability. Similar findings were found in the study of Abdullah, Parvez, and Ayreen (2014) on Bangladeshi banks, and Karim, Sami, and Hichem (2010) on African Islamic banks. Credit risk or loan-loss provision is the main contributor to the fluctuation in profitability according to Beatty and Liao (2009). However, Dietrich and Wanzenreid (2011) stated that profitability is not affected by low loan loss provisions, based on the study of commercial banks in Switzerland.

External determinants of bank profitability, including GDP and inflation, are beyond the bank's management control (Vong \& Chan, 2009). There are various findings of the impact of GDP on bank profitability. GDP growth is directly proportional to the demand for credit, which means that when the GDP trend increases, the demand for credit is high and vice versa (Ongore \& Kusa, 2013). Bilal,
Saeed, Gull, and Akram (2013), in their study of Pakistan banks, have found that real GDP has a positive impact on ROE. In the study of 354 banks from 12 Western European countries between 2000 and 2009, only GDP growth has a significant positive effect on ROA (Van Ommeren, 2011). However, ROA was not affected by GDP, according to the study of Simiyu and Ngile (2015) on Kenya commercial banks.

Inflation, measured by the Consumer Price Index (Alalaya \& Al Khattab, 2015), can affect earnings by eroding the value of money while also affecting the value of any real assets held. Pasiouras and Kosmidou (2007), in the study of 584 European banks from 1995 to 2001, show that inflation has a small positive influence on profitability of domestic banks and a negative influence on foreign banks. In the study of Chowdhury (2015) on Islamic banks, inflation rate has a positive significant impact on ROA.

Some studies argued that GDP and inflation influence bank profitability. There is a linear effect of the increase in GDP growth on Sub-Saharan African commercial banks' ROA, implying greater loan demands from financial institutions during the cyclical upswings (Flamini, McDonald, \& Schumacher, 2009). The same study reveals that inflation has a positive effect on ROA. Findings of the study of Ongore and Kusa (2013) on Kenya commercial banks revealed that GDP and inflation have a significant negative effect on ROA and ROE. Kanwal and Nadeem (2013) focused on the public limited commercial banks in Pakistan and concluded that GDP had no effect on ROE and ROA. Inflation rate, on the other hand, has a negative relationship with both profitability measures on the same study. Kiganda (2014) has determined that GDP and inflation are insignificant to profitability of banks in Kenya. Aslam, Inamullah, and Ismail (2016), in the study of on Pakistan banks and Abdullah, Parvez, and Ayreen (2014) on Bangladesh banks, found that GDP growth and inflation rate have a negative impact on ROA. 


\section{DATA AND METHODOLOGY}

The effect of credit risk, GDP growth rate and inflation rate on profitability of the top five banks in ASEAN countries was analyzed. Credit risk was calculated by dividing the reserve on loan loss by the total portfolio of loans. Two dimensions of bank profitability were measured: ROE (net profit/ total equity) and ROA (net profit/total assets). This study aims to explain the results in the Philippines, Thailand, Indonesia and Malaysia for the top five banks.

The study is based on Hawley's risk bearing theory of profit in 1900. The theory emphasized that profit is a reward for risk taking. For different businesses, the degree of risk varies.

Secondary data used in the study was extracted from each country's central banks' websites, financial statements, related journals and other relevant reports. Online databases, such as Thomson Reuters Eikon, Central Banks and financial statements, were sources of data.

Data was analyzed using SPSS. Initially, heteroscedasticity (unequal variance) and data normality were detected. Then, panel data was used to examine the fixed and/or random effects of the entity (banks per country) or time (2012-2017). In addition, the study used regression with bootstrapping to investigate the effects of credit risk, GDP growth, and inflation rate on ROE and ROA.

\section{RESULTS AND DISCUSSION}

The descriptive statistics showed that there were 120 total observations (20 cross-section and 6 -year data). ROE (\%) has a minimum of $1.5 \%$ and a maximum of $32.61 \%$ with the dispersion of $31.11 \%$. Average ROE was $14.47 \%$ and a deviation was $5.5 \%$. Return on assets (ROA in \%) has a min- imum of $0.18 \%$ and a maximum of $3.66 \%$ with a dispersion of $3.48 \%$. ROA has an average of $1.59 \%$ with the $0.74 \%$ standard deviation. Credit risk (\%) has a minimum of $-0.05 \%$ and a maximum of $3.81 \%$ with a dispersion of $3.85 \%$. Average credit risk was $0.86 \%$ with standard deviation of $0.83 \%$. GDP growth (\%) has a minimum of $0.98 \%$ and a maximum of $7.24 \%$ with a dispersion of $6.26 \%$. GDP growth was $5.15 \%$ with the $1.51 \%$ standard deviation. Inflation rate (\%) has a minimum of -0.90 and a maximum of $6.41 \%$ with a dispersion of $7.31 \%$. The average increase is $2.77 \%$ with the standard deviation of $1.83 \%$.

The above descriptive statistics showed that the wide range of dispersion implies inliers and outliers. Also, the deviation from the mean indicated the wide margin of error from the mean. The remedy was to transform the data to natural logarithm to smooth large discrepancies in data that could affect the result of regression. However, the transformation to natural logarithm was not possible because of negative or zero values in the observation.

Before the regression can be run, heteroscedasticity (unequal variance) and data normality were detected to determine the appropriate regression model. Levene's test assesses this assumption. A test for homogeneity or homoscedasticity in Table 2 showed that p-values (sig. < 0.5 ) were less than 0.05 . The unequal variances were assumed and it was concluded that data was heteroscedastic.

Table 2. Variance homogeneity test

\begin{tabular}{l|c|c|c|c}
\hline \multicolumn{1}{c|}{ Indicator } & Levene statistics & $\mathbf{d f 1}$ & $\mathbf{d f 2}$ & Sig. \\
\hline ROE (\%) & 9.921 & 1 & 118 & .002 \\
\hdashline ROA (\%) & 21.605 & 1 & 118 & .000 \\
\hdashline Credit risk (\%) & 35.451 & 1 & 118 & .000 \\
\hline GDP growth (\%) & 40.742 & 1 & 118 & .000 \\
\hline Inflation rate (\%) & 6.808 & 1 & 118 & .010 \\
\hline
\end{tabular}

Table 1. Descriptive statistics

\begin{tabular}{|c|c|c|c|c|c|c|}
\hline Indicator & $\mathbf{N}$ & Range & Minimum & Maximum & Mean & Std. deviation \\
\hline ROE (\%) & 120 & 31.11 & 1.50 & 32.61 & 14.47 & 5.50 \\
\hline ROA (\%) & 120 & 3.48 & .18 & 3.66 & 1.59 & 0.74 \\
\hline Credit risk (\%) & 120 & 3.85 & -.05 & 3.81 & 0.86 & 0.83 \\
\hline GDP growth (\%) & 120 & 6.26 & .98 & 7.24 & 5.15 & 1.51 \\
\hline Inflation rate (\%) & 120 & 7.31 & -.90 & 6.41 & 2.77 & 1.83 \\
\hline
\end{tabular}


Table 3. Normality test - Philippines vs Malaysia

\begin{tabular}{|c|c|c|c|c|c|c|c|}
\hline \multirow{2}{*}{\multicolumn{2}{|c|}{ Indicator }} & \multicolumn{3}{|c|}{ Kolmogorov-Smirnov ${ }^{\mathrm{a}}$} & \multicolumn{3}{|c|}{ Shapiro-Wilk } \\
\hline & & Statistics & df & Sig. & Statistics & df & Sig. \\
\hline \multirow[t]{2}{*}{$\mathrm{ROE}(\%)$} & 0 & 0.080 & 90.000 & $200^{*}$ & 0.979 & 90.000 & 0.160 \\
\hline & 1 & 0.112 & 30.000 & $200^{*}$ & 0.976 & 30.000 & 0.708 \\
\hline \multirow[t]{2}{*}{ ROA (\%) } & 0 & 0.187 & 90.000 & 0.001 & 0.920 & 90.000 & 0.001 \\
\hline & 1 & 0.135 & 30.000 & 0.171 & 0.855 & 30.000 & 0.001 \\
\hline \multirow{2}{*}{ Credit risk (\%) } & 0 & 0.152 & 90.000 & 0.001 & 0.878 & 90.000 & 0.001 \\
\hline & 1 & 0.131 & 30.000 & $.200^{*}$ & 0.813 & 30.000 & 0.001 \\
\hline \multirow[t]{2}{*}{ GDP growth (\%) } & 0 & 0.172 & 90.000 & 0.001 & 0.924 & 90.000 & 0.001 \\
\hline & 1 & 0.265 & 30.000 & 0.001 & 0.837 & 30.000 & 0.001 \\
\hline \multirow[t]{2}{*}{ Inflation rate (\%) } & 0 & 0.141 & 90.000 & 0.001 & 0.926 & 90.000 & 0.001 \\
\hline & 1 & 0.262 & 30.000 & 0.001 & 0.845 & 30.000 & 0.001 \\
\hline
\end{tabular}

Note: 0 - Malaysia (Msa), 1 - Philippines (Phl), ${ }^{\text {a }}$ Lilliefors Significance Correction, ${ }^{*}-$ a lower bound of the true significance.

Table 4. Normality test - Indonesia vs Malaysia

\begin{tabular}{|c|c|c|c|c|c|c|c|}
\hline \multirow{2}{*}{\multicolumn{2}{|c|}{ Indicator }} & \multicolumn{3}{|c|}{ Kolmogorov-Smirnov ${ }^{a}$} & \multicolumn{3}{|c|}{ Shapiro-Wilk } \\
\hline & & \multirow{2}{*}{$\begin{array}{c}\text { Statistics } \\
0.065\end{array}$} & \multirow{2}{*}{$\begin{array}{c}\text { df } \\
90.000\end{array}$} & \multirow{2}{*}{$\begin{array}{l}\text { Sig. } \\
.200^{*}\end{array}$} & \multirow{2}{*}{$\begin{array}{c}\text { Statistics } \\
0.987\end{array}$} & \multirow{2}{*}{$\begin{array}{c}\text { df } \\
90.000\end{array}$} & \multirow{2}{*}{$\begin{array}{c}\text { Sig. } \\
0.511\end{array}$} \\
\hline ROE (\%) & 0 & & & & & & \\
\hline & 1 & 0.129 & 30.000 & $.200^{*}$ & 0.974 & 30.000 & 0.667 \\
\hline \multirow[t]{2}{*}{ ROA (\%) } & 0 & 0.119 & 90.000 & 0.003 & 0.935 & 90.000 & 0.001 \\
\hline & 1 & 0.125 & 30.000 & $.200^{*}$ & 0.939 & 30.000 & 0.087 \\
\hline \multirow[t]{2}{*}{ Credit Risk (\%) } & 0 & 0.148 & 90.000 & 0.001 & 0.868 & 90.000 & 0.001 \\
\hline & 1 & 0.150 & 30.000 & 0.082 & 0.932 & 30.000 & 0.055 \\
\hline \multirow[t]{2}{*}{ GDP Growth (\%) } & 0 & 0.176 & 90.000 & 0.001 & 0.907 & 90.000 & 0.001 \\
\hline & 1 & 0.348 & 30.000 & 0.001 & 0.760 & 30.000 & 0.001 \\
\hline \multirow[t]{2}{*}{ Inflation Rate (\%) } & 0 & 0.139 & 90.000 & 0.001 & 0.936 & 90.000 & 0.001 \\
\hline & 1 & 0.330 & 30.000 & 0.001 & 0.700 & 30.000 & 0.001 \\
\hline
\end{tabular}

Note: 0 - Malaysia (Msa), 1 - Indonesia (Ina), ${ }^{\text {a }}$ Lilliefors Significance Correction, ${ }^{*}-$ a lower bound of the true significance.

Table 5. Normality test - Thailand vs Malaysia

\begin{tabular}{|c|c|c|c|c|c|c|c|}
\hline \multirow{2}{*}{ Indicator } & & \multicolumn{3}{|c|}{ Kolmogorov-Smirnov ${ }^{\mathrm{a}}$} & \multicolumn{3}{|c|}{ Shapiro-Wilk } \\
\hline & & Statistics & df & Sig. & Statistics & df & Sig. \\
\hline \multirow[t]{2}{*}{$\mathrm{ROE}(\%)$} & 0 & 0.087 & 90.000 & 0.086 & 0.979 & 90.000 & 0.158 \\
\hline & 1 & 0.102 & 30.000 & $.200^{*}$ & 0.961 & 30.000 & 0.323 \\
\hline \multirow[t]{2}{*}{ ROA (\%) } & 0 & 0.186 & 90.000 & 0.001 & 0.896 & 90.000 & 0.001 \\
\hline & 1 & 0.117 & 30.000 & $.200^{*}$ & 0.955 & 30.000 & 0.227 \\
\hline \multirow[t]{2}{*}{ Credit Risk (\%) } & 0 & 0.239 & 90.000 & 0.001 & 0.745 & 90.000 & 0.001 \\
\hline & 1 & 0.156 & 30.000 & 0.060 & 0.925 & 30.000 & 0.036 \\
\hline \multirow[t]{2}{*}{ GDP Growth (\%) } & 0 & 0.163 & 90.000 & 0.001 & 0.944 & 90.000 & 0.001 \\
\hline & 1 & 0.255 & 30.000 & 0.001 & 0.824 & 30.000 & 0.001 \\
\hline \multirow[t]{2}{*}{ Inflation Rate (\%) } & 0 & 0.173 & 90.000 & 0.001 & 0.896 & 90.000 & 0.001 \\
\hline & 1 & 0.205 & 30.000 & 0.002 & 0.897 & 30.000 & 0.007 \\
\hline
\end{tabular}

Note: 0 - Malaysia (Msa), 1 - Thailand (Thai), a - Lilliefors Significance Correction, * - a lower bound of the true significance.

Since the dataset has 120 elements, less than 2000 elements, the Shapiro-Wilk test was used. From Tables 3, 4 and 5, most $p$-values were less than 0.05 . The alternative hypothesis was rejected and it was concluded that the data was not normal.
Panel data was explored to determine fixed and/ or random effects of entity (banks per country) or time (2012-2017). The role of dummy variables is the basis for core variance between fixed and random effect models: 


$$
Y_{i t}=x_{i t} B+z_{\delta}+e_{i t} \text {, }
$$

where $i=1, \ldots 20$ and $t=1, \ldots \ldots, 6$; $Y-$ ROE, ROA (all in percentage), $X_{i}$ - credit risk, GDP growth, and inflation rate (all in percentage), $z_{\delta}$ - dummy variables,

$$
\begin{array}{ll}
z_{1}: & 1=\text { Philippines }(\mathrm{Phl}), 0=\text { Malaysia }(\mathrm{Msa}) \\
z_{2}: & 1=\text { Indonesia }(\text { Ina), } 0=\text { Malaysia }(\mathrm{Msa}) \\
z_{3}: & 1=\text { Thailand (Thai), } 0=\text { Malaysia (Msa) }
\end{array}
$$

In a fixed effects model, dummies are considered as part of the intercept, while they act as an error term in a random effect model. Assuming the same slopes and constant variance across entities or subjects, a fixed group effect model examines group differences in intercepts. Since a group (individual specific) effect is time invariant and considered a part of the intercept, $z_{\delta}$ is allowed to be correlated to other regressors. Least squares dummy variable (LSDV) and effect estimation methods are used by fixed effect models. In fact, fixed effect models are the ordinary least squares (OLS) regressions with dummies.

Dummy variable provides the source of diversity (heteroscedasticity) and difference in regression model structure. With violation in normality and homoscedasticity, the dummy variable provided a means in violations of normality and homoscedasticity and indicated a change in model structure. Equation (1) or the full model cannot be used in this study because of structural instability discussed above.

For each dummy variable, equations can be stated as follows:

Philippines vs Malaysia

$$
\begin{aligned}
& R O E_{(P h l)}=(b 0+z 1)+b 1 \cdot \text { credit risk }+ \\
& +b 2 \cdot \text { gdp growth }+b 3 \cdot \text { inflation rate }+e_{i t} .
\end{aligned}
$$

Indonesia vs Malaysia

$$
\begin{aligned}
& R O E_{(\text {Ina) }}=(b 0+z 2)+\text { b1 } \cdot \text { credit risk }+ \\
& +b 2 \cdot \text { gdp growth }+ \text { b3 } \cdot \text { inflation rate }+e_{i t} .
\end{aligned}
$$

Thailand vs Malaysia

$$
\begin{aligned}
& R O E_{(\text {Thai })}=(b 0+z 3)+b 1 \cdot \text { credit risk }+ \\
& b 2 \cdot \text { gdp growth }+b 3 \cdot \text { inflation rate }+e_{i t} .
\end{aligned}
$$

Malaysia (if Philippines, Indonesia and Thailand $=0$ )

$$
\begin{aligned}
& R O E_{(M s a)}=b 0+b 1 \cdot \text { credit risk }+ \\
& +b 2 \cdot g d p \text { growth }+b 3 \cdot \text { inflation rate }+e_{i t} .
\end{aligned}
$$

Malaysia was arbitrarily assigned a zero value to conform with the $\mathrm{K}-1$ requirement in regression and to avoid perfect multicollinearity.

$$
\begin{aligned}
& R O A_{(P h l)}=(b 0+z 1)+b 1 \cdot \text { credit risk }+ \\
& +b 2 \cdot \text { gdp growth }+b 3 \cdot \text { inflation rate }+e_{i t} .
\end{aligned}
$$

Indonesia vs Malaysia

$$
\begin{aligned}
& R O A_{(\text {Ina })}=(b 0+z 2)+b 1 \cdot \text { credit risk }+ \\
& +b 2 \cdot g d p \text { growth }+b 3 \cdot \text { inflation rate }+e_{i t} .
\end{aligned}
$$

\section{Thailand vs Malaysia}

$$
\begin{aligned}
& R O A_{(\text {Thai })}=(b 0+z 3)+b 1 \cdot \text { credit risk }+ \\
& +b 2 \cdot \text { gdp growth }+ \text { b3 } \cdot \text { inflation rate }+e_{i t} .
\end{aligned}
$$

Malaysia (if Philippines, Indonesia and Thailand $=0$ )

$$
\begin{aligned}
& R O A_{(\text {Msa })}=b 0+b 1 \cdot \text { credit risk }+ \\
& +b 2 \cdot \text { gdp growth }+ \text { b3 } \cdot \text { inflation rate }+e_{i t} .
\end{aligned}
$$

This study used regression with bootstrapping to determine the influence of credit risk, GDP growth and inflation rate on ROE and ROA. Bank characteristics per country of origin (Philippines, Indonesia, Thailand, and Malaysia) were included in the regression model in nominal measures. Malaysia was selected as an arbitrary benchmark. The characteristics of the selected ASEAN countries provided the variability or differences needed to describe banks.

The regression outcomes supported that credit risk and GDP growth negatively affect ROE at the $5 \%$ level of significance (Table 6). The increase in credit risk and GDP decrease the ROE of banks. The growth of inflation rate increases ROE by $0.323 \%$ implying that ROE increases with the currency devaluation. In order of effects, inflation (0.107) has the highest effect on 
Table 6. Regression results on ROE

\begin{tabular}{|c|c|c|c|c|}
\hline \multirow{2}{*}{ Model } & Unstandardized coefficients & Standardized coefficients & \multirow{2}{*}{ Sig. (2-tailed) } & \multirow{2}{*}{ VIF } \\
\hline & B & Beta & & \\
\hline (Constant) & 14.503 & & .001 & \\
\hline Credit risk (\%) & -4.248 & -.639 & .001 & 1.769 \\
\hline GDP growth (\%) & -.199 & -.055 & .001 & 2.239 \\
\hline Inflation rate (\%) & .323 & .107 & .001 & 2.838 \\
\hline $1=\mathrm{Phl}, 0=\mathrm{Msa}$ & .513 & .041 & .001 & 1.891 \\
\hline $1=\ln a, 0=M s a$ & 10.154 & .803 & .001 & 3.762 \\
\hline $1=$ Thai, $0=$ Msa & 4.283 & .339 & .001 & 2.426 \\
\hline \multicolumn{5}{|c|}{ Dependent variable: ROE (\%) } \\
\hline \multicolumn{5}{|c|}{$F(0.001)=15.19$, Adj $R$-squared $=41.7$} \\
\hline
\end{tabular}

Table 7. Regression results on ROA

\begin{tabular}{|c|c|c|c|c|}
\hline \multirow{2}{*}{ Model } & Unstandardized coefficients & Standardized coefficients & \multirow{2}{*}{ Sig. (2-tailed) } & \multirow{2}{*}{ VIF } \\
\hline & B & Beta & & \\
\hline (Constant) & 1.33 & & 0.001 & \\
\hline Credit risk (\%) & -0.44 & -0.50 & 0.001 & 1.77 \\
\hline GDP growth (\%) & -0.03 & -0.07 & 0.001 & 2.24 \\
\hline Inflation rate (\%) & 0.02 & 0.05 & 0.001 & 2.84 \\
\hline $1=\mathrm{Phl}, 0=\mathrm{Msa}$ & 0.45 & 0.27 & 0.001 & 1.89 \\
\hline $1=\operatorname{Ina}, 0=\mathrm{Msa}$ & 1.85 & 1.10 & 0.001 & 3.76 \\
\hline $1=$ Thai, $0=$ Msa & 0.67 & 0.39 & 0.001 & 2.43 \\
\hline \multicolumn{5}{|c|}{ Dependent variable: ROA (\%) } \\
\hline \multicolumn{5}{|c|}{$F(0.001)=30.62$, Adj R-squared $=60.0$} \\
\hline
\end{tabular}

ROE followed by GDP growth and credit risk. Indonesia (0.803) has the highest ROE followed by Thailand and the Philippines. Malaysia has the lowest incidence of ROE.

Since all the B-coefficients were significant at the $5 \%$ level, the finding of the study is that credit risk, GDP growth and inflation rate had an impact on ROE in 2012-2017. There were significant differences in ROE of countries as reflected by dummy variables.
Regression on ROA (Table 7) has a similar result with ROE. Credit risk and GDP growth negatively affect ROA at $5 \%$ level of significance. This implies that higher credit risk and GDP growth decline the percentage ROA of banks in a specific country. However, increase in inflation rate impacts the percent increase in ROA. ROA seems to increase because of currency devaluation. Across the country, Indonesia, Thailand and the Philippines have the highest ROA in 2012-2017. Malaysia has the lowest ROA during the period analyzed.

\section{CONCLUSION}

The study found that credit risk and GDP growth have a negative impact on ROE at 5\% level of significance. An increase in inflation rate increases ROE by $0.323 \%$ implying that ROE increases with the devaluation of the currency. In terms of effects, inflation (0.107) has the highest effect on ROE, followed by GDP growth and credit risk. Indonesia has the highest ROE, followed by Thailand and the Philippines. Malaysia has the lowest incidence of ROE.

The regression on ROA has a similar result with ROE. Credit risk and GDP growth negatively affect ROA at 5\% level of significance. Higher credit risk and GDP growth reduce the percentage ROA of banks in a specific country. The inflation rate upward trending influences the percent increase in ROA. 
ROA seems to increase because of currency devaluation. Across the country, Indonesia, Thailand and the Philippines have the highest ROA in 2012-2017. Malaysia has the lowest ROA during the period analyzed.

The study recommends strengthening banks' credit policies with respect to the $5 \mathrm{C}$ 's of borrower creditworthiness (Capacity, Collateral, Capital, Conditions, and Character) in their valuation of a borrower's credit standings before they extend credit to the borrowers. The negative effect of the loan-loss ratio should be taken into account by bank managers. In addition, bank managers should consider significant macroeconomic variables as they may represent either threats or additional opportunities for banks.

Depositors should maintain accounts in profitable banks as this will reduce the risk of bankruptcy-related losses. Investors, on the other hand, should invest in countries whose economy is booming, as evidenced by the results of GDP growth.

Due to the positive and significant effects of real GDP growth, policymakers must create policies that will stimulate a healthier economy, such as free trade deals, cutting red tape and fees for registering new businesses and incentives for startups to motivate businessmen to establish new business. Increasing business will increase bank profitability. Inflation rate is significant in the commercial banks in the ASEAN region and can be significant when measured against banks in other world regions. Thus, it is recommended that policy makers investigate such variables in other regions.

Researchers can use this study as a basis for research in the ASEAN region using variables not included in this study or similar studies with other countries not covered. Other potential determinants of profitability that can be tested include the use of control variables or other variables, such as the term structure of interest rates. Venturing into countries or associations may also be worth considering. They could check whether the profitability determinants of ASEAN banks in this study were applicable across European, American and other developed countries.

\section{REFERENCES}

1. Abdullah, M., Parvez, K., \& Ayreen, S. (2014). Bank specific, industry specific and macroeconomic determinants of commercial bank profitability: a case of Bangladesh. World Journal of Social Science, 4(3), 82-96. Retrieved from https:// www.researchgate.net/publication/320930850_Bank_Specific_ Industry_Specific_and_Macroeconomic_Determinants_of_Commercial_Bank_Profitability_A_ Case_of_Bangladesh

2. Ahmad, F., Tahir, S., \& Aziz, B. (2014). Impact of Loan Loss Provision on Bank Profitability in Pakistan. Research Journal of Social Science Management, 3(12), 34-38. Retrieved from https:// www.researchgate.net/publication/279931829_Impact_of_Loan_ Loss_Provision_on_Bank_Profitability_in_Pakistan
3. Ahmad, S. Nafees, B. \& Khan, Z. A. (2012). Determinants of Profitability of Pakistani Banks: Panel Data Evidence for the period 2001-2010. Journal of Business Studies Quarterly, 4(1), 149-165. Retrieved from https://www.researchgate.net/ publication/233923537_DETERMINANTS_OF_PROFITABILITY_OF_DOMESTIC_PAKISTANI_BANKS

4. Alalaya, M., \& Al Khattab, S. A. (2015). A Case Study in Business Market: Banks' Profitability: Evidence from Jordanian Commercial Banks (2002-2015). International Journal of Business Management \& Economic Research, 6(4), 204-213. Retrieved from http://www.ijbmer.com/ docs/volumes/vol6issue4/ijbmer2015060401.pdf
5. Ani, W. U., Ugwunta, D. O., Ezeudu, I. J., \& Ugwuanyi, G. O. (2012). An empirical assessment of the determinants of bank profitability in Nigeria: Bank characteristics panel evidence. Journal of Accounting and Taxation, 4(3), 38-43. http://dx.doi. org/10.5897/JAT11.034

6. ASEAN Secretariat. (2008). ASEAN Economic Community Blueprint. Retrieved from https:// asean.org/wp-content/uploads/ archive/5187-10.pdf

7. Asian Development Bank. (2013). The road to ASEAN financial integration: A combined study on assessing the financial landscape and formulating milestones for monetary and financial integration in ASEAN. Retrieved from https:// www.adb.org/sites/default/files/ publication/30202/road-aseanfinancial-integration.pdf 
8. Aslam, M. K., Inamullah, \& Ismail, M. (2016). Determinants affecting the profitability of Islamic banks: evidence from Pakistan. International Journal of Operations and Logistics Management, 5(2), 115-127. Retrieved from https:// www.academia.edu/26943192/Determinants_Affecting_the_Profitability_of_Islamic_Banks_Evidence from_Pakistan

9. Beatty, A., \& Liao, S. (2009). Regulatory capital ratios, loan loss provisioning and pro-cyclicality. Retrieved from http://citeseerx.ist. psu.edu/viewdoc/download?doi $=10.1 .1 .453 .6911 \& \mathrm{rep}=\mathrm{rep} 1 \&$ typ $\mathrm{e}=\mathrm{pdf}$

10. Bilal, M., Saeed, A., Gull, A., \& Akram, T. (2013). Influence of Bank-Specific and Macroeconomic Factors on the Profitability of Commercial Banks: A Case Study of Pakistan. Research Journal of Finance and Accounting, 4(2), 117-126. Retrieved from https://www.iiste.org/Journals/index.php/RJFA/article/ view/4438/4506

11. Chowdhury, M. A. F. (2015). Which is more important in terms of Profitability of Islamic Banks: Bank Specific factors or Macroeconomic factors? An Empirical Study on Malaysian Islamic Banks. European Journal of Islamic Finance, 2, 1-9. http:// dx.doi.org/10.13135/24212172/922

12. Chowdhury, E. K. (2012). Impact of Inflation on Bank Lending Rates in Bangladesh. Journal of Politics \& Governance, 19(1), 5-13. Retrieved from https://www.researchgate. net/publication/303763420_Impact_of_Inflation_on_Bank_Lending_Rates_in_Bangladesh

13. Deorukhkar, S., \& Xia, L. (2015). Digital Banking In Emerging Asia: Progress and Prospects. México: BBVA Research Inc Retrieved from https://www. bbvaresearch.com/wp-content/ uploads/2015/10/151013_DigitalBanking-in-Asia.pdf

14. Dietrich, A., \& Wanzenreid, G. (2011). Determinants of Bank Profitability Before and During the Crisis: Evidence from Switzerland. Journal of International Financial Markets, Institutions and Money, 21(3), 307-327. Retrieved from https:// papers.ssrn.com/sol3/papers. cfm?abstract_id=1370245

15. Elsas, R., Hackethal, A., \& Holzhäuser, M. (2010). The anatomy of bank diversification. Journal of Banking and Finance, 34(6), 1274-1287. https:// doi.org/10.1016/j.jbankfin.2009.11.024

16. Flamini, V., McDonald, C., \& Schumacher, L. (2009). The determinants of commercial bank profitability in Sub-Saharan Africa (IMF Working paper No. WP/09/15). Retrieved from https://www.imf.org/external/ pubs/ft/wp/2009/wp0915.pdf

17. Gizaw, M., Kebede, M., \& Selvaraj, S. (2015). The impact of credit risk on profitability performance of commercial banks in Ethiopia African Journal of Business Management, 9(2), 59-66. https:// doi.org/10.5897/AJBM2013.7171

18. Hawley, F. B. (1900). Enterprise and profit. Quarterly Journal of Economics, 15(1), 75-105. http:// dx.doi.org/10.2307/1885862

19. Hirose, M., Murakami, T., \& Oku, Y. (2004). Development of the Asian Bond Markets and Business Opportunities (NRI Paper, No. 82). Nomura Research Institute. Retrieved from https://www.nri. com/global/opinion/papers/2004/ pdf/np200482.pdf

20. Kanwal, S., \& Nadeem, M. (2013). The Impact of Macroeconomic Variables on the Profitability of Listed Commercial Banks in Pakistan. European Journal of Business and Social Sciences, 2(9), 186-201. Retrieved from https:// www.academia.edu/6201984/ THE_IMPACT_OF_MACROECONOMIC VARIABLES ON_THE_PROFITABILITY OF_LISTED_COMMERCIAL_ BANKS_IN_PAKISTAN

21. Karim, B. K., Sami, B. A., \& Hichem, B. K. (2010). Bankspecific, industry-specific and macroeconomic determinants of African Islamic banks' profitability. International Journal of Business and Management Science, 3(1), 39-56. Retrieved from http://www. safaworld.org/ijbms/abs/abs3.1/ IJBMS03\%20Ben\%2039-56.pdf

22. Kiganda, E. O. (2014). Effect of Macroeconomic Factors on Commercial Banks Profitability in Kenya: Case of Equity Bank Limited. Journal of Economics and Sustainable Development, 5(2), 46-56. Retrieved from https:// www.iiste.org/Journals/index.php/ JEDS/article/view/10697/10902

23. Kohler, M. (2013). Does noninterest income make banks more risky? Retail-versus investment-oriented banks. Review of Financial Economics, 23, 182-193. https://doi.org/10.1016/j. rfe.2014.08.001

24. Masood, O., Ashraf, M., \& Turen, S. (2015). Bank-Specific and Macroeconomic Determinants of Bank Profitability: Evidence from Member States of the OIC. Journal of Islamic Financial Studies, 1(1), 43-51. Retrieved from https://pdfs. semanticscholar.org/6a0b/4a334 148b33b11c4a30397e63b24f754dca3.pdf

25. Maudos, J. \& Guevara, J. F. (2004). Factors explaining the interest margin in the banking sectors of the European Union. Journal of Banking and Finance, 28(9), 22592281. https://doi.org/10.1016/j.jbankfin.2003.09.004

26. Muhamet, A., \&Arbana, S. (2016). The Effect of Credit Risk Management on Banks' Profitability in Kosovo. European Journal of Economic Studies, 18(4), 492-515. https://doi.org/10.13187/ es.2016.18.492

27. Mustafa, A., Ansari, R., \& Younis, M. (2011). Does the Loan Loss Provision Affect the Banking Profitability in Case of Pakistan? Asian Economic and Financial Review, 2(7), 772-783. Retrieved from https://ideas.repec.org/a/asi/ aeafrj/2012p772-783.html

28. Ongore, V., \& Kusa, G. (2013). Determinants of Financial Performance of Commercial Banks in Kenya. International Journal of Economics and Financial Issues, 3(1), 237-252. 
Retrieved from https://pdfs. semanticscholar.org/b303/ a60a53b66900b72b38fbcd964d3983b7af0c.pdf

29. Pasiouras, F., \& Kosmidou, K. (2007). Factors influencing the profitability of domestic and foreign commercial banks in the European Union. Research in International Business and Finance, 21(2), 222-237. https://doi. org/10.1016/j.ribaf.2006.03.007

30. Saunders, A., \& Schumacher, L. (2000). The determinants of bank interest rate margins: an international study. Journal of International Money and Finance, 19(6), 813-832. https://doi. org/10.1016/S02615606(00)00033-4

31. Simiyu, C., \& Ngile, L. (2015). Effect of Macroeconomic Variables on Profitability of
Commercial Banks Lsited in the Nairobi Securities Exchange. International Journal of Economics, Commerce and Management, III(4), 1-16. Retrieved from http:// ijecm.co.uk/wp-content/uploads/2015/04/3411.pdf

32. Van Ommeren, S. (2011). An examination of the determinants of banks' profitability in the European banking sector (Unpublished master's thesis). Rotterdam: Erasmus University.

33. Vidal-Abarca, A. O., Xia, L., Deorukhkar, S., Rodrgo, T., \& Ugarte, A. (2017). Fintech in Emerging ASEAN Trends and Prospects. Spain: BBVA Research Inc. Retrieved from https://www. bbvaresearch.com/wp-content/uploads/2017/07/June-2017-ASEANFintech-Trends1.pdf
34. Vong, P., \& Chan, H. (2008). Determinants of Bank Profitability in Macau. The $30^{\text {th }}$ Anniversary of Journal of Banking and Finance Conference (pp. 93-113). Retrieved from http://citeseerx.ist.psu.edu/ viewdoc/download?doi=10.1.1.53 $3.7516 \&$ rep $=$ rep $1 \&$ type $=$ pdf

35. Wasiuzzaman, S., \& Tarmizi, H. A. B. A. (2010). Profitability of Islamic banks in Malaysia: an empirical analysis. Journal of Islamic Economics, Banking and Finance, 6(4), 53-68. Retrieved from http://ibtra.com/pdf/journal/ v6_n4_article3.pdf

36. Zarrouk, H. (2012). Does financial crisis reduce Islamic banks' performance? Evidence from GCC Countries. Journal of Islamic Finance and Business Research, 1(1), 1-16 